\title{
Students' Perception, Expectation and Satisfaction toward the Characteristics of Female Lecturers in Higher Education
}

\author{
Nur Idayu Badrolhisam*, Norhidayah Mohd Rashid, Hairunisa Ma’amor, \\ Mohamad Naqiuddin Md Mansor, Siti Norashikin Bashirun \\ Faculty of Business and Management, Universiti Teknologi MARA (UiTM), Malaysia
}

Received June 28, 2019; Revised September 5, 2019; Accepted September 12, 2019

Copyright@2019 by authors, all rights reserved. Authors agree that this article remains permanently open access under the terms of the Creative Commons Attribution License 4.0 International License

\begin{abstract}
Students' perceptions, expectations and satisfaction in higher education are vital to be measured in order to improve the quality of higher education institutions. The paper focuses on these three variables specifically as well as the characteristics of female lecturers in higher education. There are many studies that focused on the teaching quality among lecturers in higher education, but few have provided emphasis on female lecturers and their traits for improvement of higher education establishments. To better understand the characteristics of female lecturers, the study sampled 134 students in a Malaysian public university to gauge their level of perception, expectation and satisfaction. The study found that female lecturers have the best soft-skills which in turn, make the students feel comfortable and welcomed in higher education institutions. At the same time, the students expect female lecturers to be more knowledgeable despite the fact that most of them feel very satisfied with the knowledgeability portrayed by female lecturers.
\end{abstract}

Keywords Female Lecturers, Characteristics, Students' Perception, Students' Expectation, Students' Satisfaction

\section{Introduction}

In higher education, students are considered the external customers that should be treated equally like clients in the corporate world. Their perception and expectation on higher education institutions should not be taken lightly and should be taken into account to help the organizations to improve their efficiency in customer service. Customer satisfaction in higher education begins with the expectations and experiences of the customers that have been created upon the service delivered by many parties [1]. Likewise, the students' evaluation on the lecturers' performance can be a good indicator of teaching performance where it will improve personnel developments and educational standards [2].

In the context of lecturers' effectiveness, the evaluations from students influenced the teaching performance and efficiency [3]. In Malaysia, for example, the Student Evaluation of Teaching (SET) has been used widely in many education levels to evaluate the perceptions related to teacher effectiveness [4]. At the same time, the students' academic performance is affected by teaching effectiveness, the environment and facilities as well as the subjects taught by the lecturers [5]. The SET on female lecturers' focuses on personality and appearance more often than male lecturers because they may have less respect professionally toward their female lecturers [6].

Nonetheless, when we are talking about the issues on teaching effectiveness, there is also a big difference between male and female lecturers. Gender bias disadvantages females because students perceive that female lecturers, although competent, are too feminine to hold the authority [7]. It is learned that male lecturers were ranked higher in the perception of being more organized and very enthusiastic compared to the female lecturers [8]. This is because the male lecturers are considered to possess organization, understanding, passion, involvement and intelligibility skills [8]. However, the students' perception on an older female lecture has activated a "mother" representation because they perceive her as having a strong work ethic, thus, resulting in the students being more focused during a short lecture [3].

Therefore, the purpose of this study was to identify students' perceptions and expectations towards female lecturers in higher education in order to gain better insight into their definition of a high-quality female lecturer based 
on several characteristics. Subsequently, the study also measured the level of students' satisfaction towards the characteristics of female lecturers.

\section{Literature Reviews}

Still, there are not many literatures on the influence of lecturer's genders on the students' evaluation for them [8]. The lecturers' effectiveness has been influenced by student evaluations that include their interest in the choice of subjects, grading expectations and reasons for enrolling in the university [3]. However, there was a limitation when the students' perception relied heavily on physical attributes to make interpretations on both genders' efficiency and rapport [3]. Also, regardless of genders, the students' perception and expectation centered more on the age and physical features of their lecturers too [9]. A woman professor received SET worse than a man professor because typically women are evaluated based on appearance, personality and perceptions of competency and intelligence [6]. An analysis found that SET evaluates their lecturers differently when they differentiate between men and women [6]. For example, older female lecturers were seen as less attractive compared to the younger ones [3].

When it comes to the characteristic of the lecturers in both genders, the students prefer the ones who are very understanding and compassionate in helping them dealing with difficult situations especially with course-related issues [10]. Furthermore, the students expect that good lecturers must possess modesty and can be trusted when it comes to teaching effectiveness [10]. In link to that, $43 \%$ students will look at the knowledge of their lecturers because they perceived them as the content specialists, therefore, the lecturers must be able to be confident, willing to answer their questions promptly of good quality, and in detailed, clear and concise manner [11]. Additionally, students stated that the lecturers' skills in lecturing and personality outweigh their gender, indicating that lecturers gender does not matter [12].

While comparing male and female lecturers, a study found that the males were rated higher in giving positive learning impacts while the females were rated excellent in class involvement [13]. Moreover, they expected the male lecturers to be more effective in work while female lecturers should spend time developing an understanding relationship with them [3]. In the SET study, they pointed out that the male lecturers embrace more positive view of SET, which means they are more accommodating and view SET as a positive outcome compared to female lecturers [4]. Conversely, good female lecturers were rated higher than male lecturers in caring and responsiveness characteristics while the male were more competent and assertive [7]. Apart from that, female lecturers performed better than the males when it comes to teaching performance where the differences were statistically significant [2].

Then again, the students who favor male lecturers are more than female lecturers [8]; as for them, being caring and responsive were not as adequate as being competence and assertive [7]. In direction to that many authors also found that female lecturers were rated lower in teaching performance than male lecturers [2]. The reason for many gender biases rating on lecturers' performance is that male students tend to give higher-ranking scores to the male lecturers instead [5].

Thus, this study would like to answer the following research questions: (1) what are the observed perceptions of the students when interacting with the female lecturers in their university? (2) what are their expectations towards the definition of high-quality female lecturers in their university? (3) what are the levels of students' satisfaction towards the characteristics of female lecturers?; this is also to help the study to identify whether female lecturers have the same characteristics as male lecturers based on the students' perception and expectation from different settings.

\section{Methodology}

The study used a quantitative research design. The set of questionnaires were modified from [7], [13] and [14], accordingly fit into the research questions of this study for data collection. The survey was distributed to 134 students in one public university. At the same time, the study used 4-point scales to measure specific perception and expectation of the students towards female lecturers in their institution. The 4-point scales were used because the combination of series of questions measure a particular trait [15].

The questions consist of five parts that include: demographic of students, profile of female lecturers, perception on characteristic portrayed by the female lecturers when interacting with students, expectation of students towards high-quality female lecturers' characteristics and students' satisfaction towards female lecturers. The envisioned characteristics, traits or behaviors used in the questionnaire were referred to trait theories. The trait theories can be used by organizations to manage various strategies using personality traits as selection tools [16]. The data were analyzed using SPSS for descriptive analysis.

\section{Result Analysis and Discussions}

The majority of the respondents in this study are female students with $85.8 \%$ compared to male students who participated in this study (14.2\%). The age range of the participants is mostly from $21-23$ years old $(79.1 \%)$ followed by $18-20$ years old (16.4\%) and the rest are over 23 years old (4.5\%). This is because normally the age of 
21-23 years old is the age range for Bachelor's Degree students (93.3\%). Diploma level students are only 4.5\%, while other level, and the study is assuming foundation level is around $2.2 \%$. The study also asked the respondents to determine the age of female lecturers whom they have interacted with and found that the majority of the female lecturers' age are from 35-44 years old (47.0\%) followed by the younger female lecturers' age ranging between 25-34 years old $(32.1 \%)$. The female lecturers that are between 45-54 years old are only 9.1\%. However, the students did not pick a range of female lecturers' age in 55 years old and above $(0.0 \%)$. At the same time, $11.9 \%$ of them do not know the age of their female lecturers. Then, the study asked whether all of the respondents know their female lecturers very well and found that only $18.7 \%$ of them say yes, while $20.1 \%$ say no. Nevertheless, $61.2 \%$ of them feel that they maybe know their female lecturer well but undecided.

For perception result, the study asked the students 17 characteristics portrayed by female lecturers when they interacted with them. Out of 17 characteristics, 6 of which were described in negative traits, such as female lecturers are dominant, cry easily, forceful, feeling superior and that they are nervous in major crisis. All six negative traits received low to lowest mean with 3.15672, 1.99254, 2.41045, 2.47015 and 2.05224 respectively. On the other hand, for positive traits, the highest mean is scored in female lecturers who has self-confident statement (100\%, mean $=3.55224$ ) when interacting with the students. This means the female lecturers always portray good self-confidence when they communicate with their students. Then, it is also known that students perceived female lectures as the ones who are knowledgeable with $97.8 \%$ agree and strongly agree with the statements combined (mean $=3.47015$ ). This is a good sign because in previous study, it is stated that in general only $43 \%$ students perceived the lecturers, both male and female, as the content specialist [11]. At the same time, the students also have a good perception towards female lecturers who show that they are independent $(97 \%$, mean $=3.45522)$. Table 1 below shows the level of mean between the 17 characteristics.

Table 1. The level of students' perception

\begin{tabular}{|c|c|c|c|}
\hline \multirow{2}{*}{ Items } & \multicolumn{2}{c|}{ Results } \\
\cline { 2 - 4 } & Rank & Mean & .49913 \\
\hline FML has self-confident & 1 & 3.5522 & .54415 \\
\hline FML is knowledgeable & 2 & 3.4701 & .55679 \\
\hline FML is independent & 3 & 3.4552 & .58963 \\
\hline FML is kind & 4 & 3.4030 & .58298 \\
\hline FML is helpful & 5 & 3.3209 & .55714 \\
\hline FML is gentle & 6 & 3.2239 & .70289 \\
\hline FML is understanding & 7 & 3.1567 & .62353 \\
\hline FML is dominant & 8 & 3.1567 & .65422 \\
\hline FML is assertive & 9 & 3.0896 & .64455 \\
\hline FML is warm & 10 & 3.0746 & .67719 \\
\hline FML is able to dedicate herself completely to others & 11 & 2.9925 & .71555 \\
\hline FML is emotional & 12 & 2.9179 & .89337 \\
\hline FML is feeling superior & 13 & 2.7910 & .89013 \\
\hline FML is forceful & 14 & 2.4701 & .95942 \\
\hline FML is nervous in major crisis & 16 & 2.4104 & .88697 \\
\hline FML cries easily & 17 & 1.9925 & .89691 \\
\hline
\end{tabular}


Next, we asked the respondents their expectation towards high-quality characteristics needed for female lecturers. In this section, we also come out with 17 characteristics in which all of them are in positive statements. The most important characteristic that the student expect high-quality female lecturers should have is understanding $(97.8 \%$, mean=3.66418). With the same percentage, the female lecturers are also expected to be knowledgeable ( $97.8 \%$, mean $=3.66418)$. This is similar to the students' perception statement of the female lecturers' knowledge. Therefore, knowledgeability of a lecturer is very vital in higher education. Nevertheless, the other expectation towards high-quality characteristics of female lecturers score more than mean $=3$. This may mean that all the high-quality characteristics are very much needed in higher education especially for female lecturers. Table 2 below summarizes the mean differences

Table 2. The level of students' expectation

\begin{tabular}{|c|c|c|c|}
\hline \multirow{2}{*}{ Items } & \multicolumn{3}{|c|}{ Results } \\
\cline { 2 - 4 } & Rank & Mean & Std. Deviation \\
\hline FML should be knowledgeable & 1 & 3.6642 & .51946 \\
\hline FML should be understanding & 2 & 3.6642 & .54764 \\
\hline $\begin{array}{c}\text { FML should have emotional } \\
\text { stability }\end{array}$ & 3 & 3.6343 & .59498 \\
\hline FML should be respectable & 4 & 3.6119 & .57400 \\
\hline FML should be sincere & 5 & 3.6045 & .60098 \\
\hline FML should be trustworthy & 6 & 3.5746 & .60545 \\
\hline FML should be ethical & 7 & 3.5746 & .59290 \\
\hline FML should be skillful & 8 & 3.5672 & .61861 \\
\hline FML should be innovative and \\
creative & 9 & 3.5672 & .52670 \\
\hline FML should be caring & 10 & 3.5522 & .64385 \\
\hline FML should be intelligent & 11 & 3.5299 & .57111 \\
\hline FML should have expertise & 12 & 3.4925 & .62222 \\
\hline FML should be attentive & 13 & 3.4701 & .62155 \\
\hline FML should be competent & 14 & 3.4403 & .59460 \\
\hline FML should be honest & 15 & 3.4104 & .63970 \\
\hline FML should be extroverted & 16 & 3.2090 & .70524 \\
\hline FML should have reputation & 17 & 3.1493 & .78047 \\
\hline
\end{tabular}

In the last section of the survey, we asked the respondents to rate the satisfaction towards teaching, learning and interaction with the female lecturers. The students are more satisfied with the knowledge of female lecturers (96.3\%, mean=3.806). Again, knowledgeability scored the highest in all three main variables: perception, expectation and satisfaction. Students also feel satisfied with the sense of professionalism shown by the female lecturers $(91.8 \%$, mean=3.2761). However, the ease of making appointment with female lecturers and grading system used by them scored lower than mean 3 with 2.9627 and 2.9851 respectively. Table 3 below shows the mean of students' satisfaction level.
Table 3. The level of students' satisfaction

\begin{tabular}{|c|c|c|c|}
\hline \multirow{2}{*}{ Items } & \multicolumn{3}{|c|}{ Results } \\
\hline & Rank & Mean & Std. Deviation \\
\hline The knowledge of FML & 1 & 3.3806 & .55920 \\
\hline $\begin{array}{l}\text { The sense of professionalism of } \\
\text { FML }\end{array}$ & 2 & 3.2761 & .60564 \\
\hline $\begin{array}{c}\text { The consistency of teaching by } \\
\text { FML }\end{array}$ & 3 & 3.2463 & .56776 \\
\hline $\begin{array}{c}\text { The teaching learning environment } \\
\text { by FML }\end{array}$ & 4 & 3.2239 & .60873 \\
\hline $\begin{array}{l}\text { The counselling and support by } \\
\text { FML }\end{array}$ & 5 & 3.2015 & .66919 \\
\hline $\begin{array}{c}\text { The disciplinary system used by } \\
\text { FML }\end{array}$ & 6 & 3.1791 & .61131 \\
\hline The friendliness of FML & 7 & 3.1493 & .69917 \\
\hline The availability of FML & 8 & 3.0448 & .65884 \\
\hline The grading system used by FML & 9 & 2.9851 & .57498 \\
\hline $\begin{array}{c}\text { The ease of making appointment } \\
\text { with FML }\end{array}$ & 10 & 2.9627 & .77950 \\
\hline
\end{tabular}

Furthermore, the study asked the students whether they know their female lecturers well to determine the level of their perception, expectation and satisfaction. We found out that there are no significant relationships between knowing their female lecturers well with their level of perception, expectation and satisfaction towards them. All three variables show more than $0.05 \mathrm{p}$ value: perception $(p=0.219)$, expectation (0.354) and satisfaction $(p=0.458)$. The table below summarizes the relationship between items

Table 4. r square between satisfaction, perception and expectation

\begin{tabular}{|c|c|c|c|c|}
\hline \multicolumn{5}{|c|}{ Results } \\
\hline Model & $R$ & $R$ Square & Adjusted R Square & $\begin{array}{c}\text { Std. Error of the } \\
\text { Estimate }\end{array}$ \\
\hline 1 & $.186^{\mathrm{a}}$ & .035 & .012 & .78390 \\
\hline
\end{tabular}

a. Predictors: (Constant), Satisfaction, Perception, Expectation

Table 5. The sig. of perception, expectation and satisfaction with variable know female lecturer well

\begin{tabular}{|c|c|c|c|c|c|}
\hline \multicolumn{7}{|c|}{ Results } \\
\hline \multirow{2}{*}{ Model } & $\begin{array}{c}\text { Unstandardized } \\
\text { Coefficients }\end{array}$ & $\begin{array}{c}\text { Standardized } \\
\text { Coefficients }\end{array}$ & \multirow{2}{*}{$t$} & \multirow{2}{*}{ Sig. } \\
\cline { 2 - 6 } & $B$ & Std. Error & Beta & & \\
\hline (Constant) & 4.134 & .818 & & 5.055 & .000 \\
\hline Expectation & -.204 & .165 & -.114 & -1.235 & .219 \\
\hline Perception & -.218 & .234 & -.084 & -.930 & .354 \\
\hline Satisfaction & -.109 & .147 & -.066 & -.744 & .458 \\
\hline
\end{tabular}

a. Dependent Variable: Know FML well

Based on the results above, knowledgeability of the lecturers appear to be the most important quality needed for female lecturers. The students will always perceive that high quality lecturers must be educated, well-informed and expert in explaining ideas in an easy manner [14]. A university is responsible for producing knowledgeable and capable graduates in order to participate in the social 
improvement and continuous economics [13], thus it should start with empowering the lecturers regardless of genders in knowledgeability and expertise.

Other than that, the study also noted that the perception level of students towards female lectures' social interaction such as being kind, helpful, gentle, understanding and able to dedicate themselves completely to others scored mean 3 and above, which shows that the female lecturers, in fact, have good social relations with the students. Even so, in this issue the social influence of female lecturers were limited than male because it is based on the degree to which their leadership styles and communication skill should be in line to accepted femininity style [17].

The female lecturers have always been rated higher and better than their male counterparts when it comes to social responsiveness and thoughtfulness towards their students [7]. However, because no male lecturers indicated in this study and fewer male students participated in, perhaps male students may tend to give higher SET to male lecturers instead [18]. Moreover, female lecturers received higher scores in grading, preparation of the course and getting feedback from the students because students expect female lecturers are well prepared, available to their needs and more precise on grading the course [18]. These are similar to the study, which they rated their female lecturers to be knowledgeable (Rank 1), understanding (Rank 2) and sincere (Rank 5).

\section{Conclusions}

This study observed that the students' have good perception, expectation and satisfaction levels toward their family lecturers. Nevertheless, since this study only focus on female lecturers, it cannot be compared with the levels toward the male lecturers. It is however assumed that with many previous studies shows the students favor the male lecturers more than female lecturers, perhaps, the students in this study will do the same if the purpose of this study includes the male lecturers. At the same time, another limitation is the little literature that focuses specifically on female lecturers that based on students' perception, expectation and satisfaction. Most of the studies were explaining the quality of the lecturers in general without specifically focus on the lecturer's genders. Other limitation of this study is that the sample size is slightly smaller compared to the previous studies, with only less than $15 \%$ male students participated in this study. Therefore, future research should ensure that both genders will be equally participated in similar study purpose so that it can be generalized.

The rationality of this study is that women have outnumbered men in tertiary education, however, they are still lag behind in highly paid jobs like engineering, math, science, technology and ultimately in teaching careers [19]. Other than that, the presence of female lecturers in higher education can help the students feel accepted because they are able to involve students more in the class [12]. The female lecturers also can make the students appreciate the university life since understanding trait of female lecturers in this study also contributes to high level of perception and expectation. They are seen as devoted figures to the students. Therefore, this study hopes that the female lecturers around the world could uphold their soft skills in order to maintain effective and harmonious social interactions not only with the students but also with other stakeholders in higher education.

\section{Acknowledgement}

Thank the students who were willing to participate in this study in order to help us to gain better insight into what they think about their female lecturers. May this study help the future female lecturers to be aware of what characteristics can help improve the students' perforrmance. Also to all current and retired female lecturers in higher education institution, this study is for you and thank you so much for upholding the excellent characteristics throughout your entire careers.

\section{REFERENCES}

[1] Abdul Hamid, J., \& Pihie, Z. A. (2004). Students' perception of the quality of teaching and learning in business studies programs. Pertanika J. Soc. Sci. \& Hum., 12(1), 71-86.

[2] Chua, L. C., \& Kho, R. K. H. (2014). Students' evaluation on teaching performance of teacher education lecturers. Retrieved from: http://www1.curtin.edu.my/tl2015/tl2013/PDF/Students\% E2\%80\%99\%20Evaluation\%20on\%20Teaching\%20Perfor mance\%20of\%20Teacher\%20Education\%20Lecturers.pdf Accessed on 6 August 2018.

[3] Joye, S. W., \& Wilson J. H. (2015). Professor age and gender affect student perceptions and grades. Journal of the Scholarship of Teaching and Learning, 15(4), 126-138.

[4] Sulong, M. S., \& Hajazi, M. Z. (2016). Perceptions of lecturers' gender and position on students evaluation of teaching. Seminar Asean 2nd Psychology \& Humanity, 635-639.

[5] Ahmad, N. A., Azizan, F. L., Rahim, N. F., Jaya, N. H., Mohd Shaipullah, N., \& Siaw, E. S. (2017). Relationship between students' perception toward the teaching and learning methods of mathematics' lecturer and their achievement in pre-university studies, 10(11), 129-134.

[6] Mitchell, K. M. W. \& Martin, J. (2018). Gender bias in student evaluations. PS: Political Science \& Politics, 51(3), 648-652.

[7] Clune, M. K. C. (2000). Students' perceptions of instructior credibility: effects of instructor sex, gender role and communication style. Doctor of Philosophy. University of 
Kansas. Kansas.

[8] Zivkovic, J., Salatian, A., Ademoh, F., \& Oborkhale, L. (2012). Students' perceptions of instructior credibility: effects of instructor sex, gender role and communication style. International Journal of Academic Research in Business and Social Sciences, 2(5), 1-9.

[9] Ciascai, L., \& Vlad, I. E. (2014). Perception of school and university students of ideal teacher behavior (ii). Educational Researcher, 30(8), 3-15.

[10] Delaney, J. G., Johnson, A. N., Johnson, T. D., \& Treslan, D. L. (2010). Students' perceptions of effective teaching in higher education. St. John's, NL, Distance Education and Learning Technologies.

[11] Lee, H. H., Kim, G. M. L. M., \& Chan, L. L. (2015). Good teaching: what matters to university students. Asia Pacific Journal of Education, 35(1), 98-110.

[12] Appiah, S. O., \& Agbelevor, E. A. (2015). Impact of lecturers' gender on learning: assessing university of Ghana students' views. Journal of Education and Practice, 6(28), 30-37. [00] Boone, H. N., \& Boone, D. A. (2012). Analyzing likert data. Journal of Extension, 50(2).

[13] Jalali, A., Islam, M. A., \& Ku Ariffin, K. H. (2011). Service satisfaction: the case of a higher learning institution in Malaysia, 4(1), 182-192.

[14] Ismail, S., Jamaludin, N., Wan Zakaria, W. Z., \& Mohd Nawi, N. (2017). A study on the accounting students' perceptions towards teaching quality at university. International Journal of Accounting, Finance and Business, 2(5), 85-89.

[15] Ng, T. W. H., Lam S. S. K. \& Feldman, D. C. (2016). Organizational citizenship behavior and counterproductive work behavior: do males and females differ? Journal of Vocational Behavior, 93, 11-32.

[16] Laube, H., Massoni, K., Sprague, J., \& Ferber, A. L. (2007). The impact of gender on the evaluation of teaching: what we know and what we can do, 19(3), 87-104.

[17] Boring, A. (2015). Gender biases in student evaluation of teachers. OFCE-PRESAGE-Sciences Po. European Union's Sevent Framework Programme

[18] Carlana, M. (2017). Stereotypes and self-stereotypes: evidence from Teachers’ Gender Bias. Job Market Paper. 